\title{
Significance of Women Leadership on Natural Conservation Movement at Rembang, Indonesia
}

\author{
D Susilo ${ }^{1}$ and A Kodir ${ }^{2}$ \\ Universitas Erlangga, Surabaya, Indonesia ${ }^{1}$ \\ Universitas Negeri Malang, Malang, Indonesia ${ }^{2}$ \\ \{daniel-16@fisip.unair.ac.id $\left.{ }^{1}\right\}$
}

\begin{abstract}
This study aims to explain the strength and leadership of women to maintain their living space. Also, this study seeks to portray the concept of nature conservation through water, soil and earth who fought relentlessly reject the establishment of the Indonesian Cement factory in the village Tegaldowo and Timbrangan, District Gunem, Rembang. An environmental issue in Rembang is important to be discussed on the depth scale. In the depths discuss area we can look in the exploitation of natural resources massively without seeing the objective conditions around. Permit the establishment of a cement factory given by the district government of Rembang to PT. Semen Indonesia isn't considering the existence of citizens who depend on the region. Licensing mine will certainly undermine the determination of the mountains of North Kendeng and Cekungan Air Tanah (CAT) Watuputih as in the conservation area. This research used an analytical research method and analysed with leadership and ecofeminism theory. Plans to build a cement factory is the beginning of the social problems that exist in rural areas and TegalomboKrembangan. This thing that causes rejection action undertaken by the majority of women and mothers who work as a peasant. The rejection of action as an effort to save the environment in the region of CAT Watuputih.
\end{abstract}

Keywords: Women, Leadership, Ecofeminism, Movement, Natural Conservation

\section{Introduction}

Rembang, a small town in the eastern part of Central Java, have a significant natural resource in Kendeng Mountain. Semen Indonesia as government owned Portland cement company want to explore the natural resource in this area. In the early of 2016, Kendeng's women made a movement to against the Semen Indonesia's plan to explore the Kendeng Mountain.In the previous research from DewiCandraningrum, Editor in Chief Indonesian Feminist Journal (JurnalPerempuan) stated on JurnalPerempuan's website about their experience in Rembang Site. Candraningrum argue the mining industry in Rembang make women in Rembang became subordinated because all of the mining profession focus on man [1]. In 2014, women in Kendeng made a movement with illegal occupation in Semen Indonesia Rembang site. In other research, Lestariningsih [2] view the resistance from women 
movement can be rooted from the history of women national hero, Kartini who buried near Rembang area. In correlation with Candraningrum's [1] experience, the Semen Indonesia destroy the women's live and taking out her husband to move in the mining industry. Goodman, Fields, and Blum found that women usually filled in a lower management position, higher management turnover, and lower average management salary levels, place greater emphasis on development and promotion of employees, and operate in nonmanufacturing industries [3]. But, in Kendeng Movement, women became a leader and significant role to against Semen Indonesia.

Since this research article was written, the effort legal steps through the review of the Supreme Court has ruled in favor of peasants in the Kendeng mountainous, Rembang City. The victory cancels an environmental permit issued by the Governor of Central Java to PT Semen Indonesia. This is based on the official website of the Supreme Court, which decided the lawsuit on October 5, 2016 [4]. Legal measures taken by Rembang women are not for the first time. Numerous times they attend the hearing of the dispute mining objects with the Semen Indonesia Company and even Governor of Central Java. There are several findings of fact that the women's movement Rembang which then makes them optimistic in making claims, among other things:

- Semen Indonesia Company was violating Presidential Decree No. 26 of 2011 concerning the establishment of Basin Groundwater premises;

- Semen Indonesia Company violated Bylaw Spatial Plan (RTRW) Java 6 The year 2010 Article 63 which states Watuputih as "Region Water Additives";

- Semen Indonesia Company violated Bylaw Spatial Plan (RTRW) Rembang No. 14 of 2011 article 19 which states that the area has been designated as 'Geology of Protected Areas';

- Whereas according to Rembang's Bylaw Spatial Plan (RTRW) No. 14 of 2011 section 27, the area of forest in the village Kadinowo, District Bulu, Rembang is not intended as an extensive industrial area;

- Whereas Semen Indonesia Company unilaterally set Factory Region as National Vital Objects, but not by the Decree of the Minister of Industry No. 620 / M-IND / KEP / $12 / 2012$ on vital national objects of industrial sectors;

- The EIA (Environmental Impacts Analysis) (AMDAL) of Semen Indonesia Company have contained an error, untruth even falsification of data information. The article mentioned in the EIA data does not correspond to the real conditions of the field;

- The number of false testimony from the Semen Indonesia Company in Semarang administrative court hearing;

This data is factual data that cannot be ignored even by law enforcement authorities and even Central Java Governor who has the authority in its territory. Also, legal action undertaken by peasants and Rembang women is directly permitted by the governor. Which means that regardless of the outcome of the decision of the court all parties must be able to respect him. For the Rembang women, it was a part of them in a democracy.

\section{Method}

Critical Research Method used as a method in this research. Chomstock argues that "Critical social research begins from the life problems of definite and particular social agents 
who may be individuals, groups, or classes that are oppressed by alienated from social processes they maintain or create but do not control [5]. Comstock argued that the method of critical research starts from the real social problems experienced by individuals, groups, or classes of oppressed and alienated from the social processes that are growing [5]. Depth interview used as a tool to reach the data and information about the women leadership in Rembang movement. The researcher used two informants, both of them is an actress of Rembang movement and the leader of motion. Miller and Glassner stated research starts from a belief that people create and maintain meaningful worlds. That's mean people by their selfcreating the meaning [6]. In this research, feminism view also used as an approach to help researcher explore the data. Critical research method with feminism approach uses a different perspective in understanding women's issues from a perspective that tends masculine [7].

Conducting "research that involves gender is a complex of socially guided perceptual, interactional, and micro-political activities that cast particular pursuits as expressions of masculine and feminine natures" [3].Saukko stated, "The methodological programme of critical, contextualize studies is, thus, driven by an interest in seriously studying the practices of the subjugated groups, such as misbehavior at school or reading romances, which may appear trivial or foolish" [8]. Saukko made analyze about the study in critical must be concern about subjugated groups. That's the point and concern how critical research strength. In the context of Rembang movement, subjugated groups are the women who lead the movement against the Semen Indonesia. Women leadership in the context of Rembang movement created a significant issue in national media.

\section{Result and discussion}

\subsection{Women's Strength to Preserve her Homeland}

Efforts to win this time they got was the fruit of a process of resistance trip is so long. Still very clearly remember the memory MsMurtini which is one of the female fighters to reject the cement factory, she stated that the rejection action undertaken by these mothers since 2012 when the cement plant will start operating. But the efforts of their movement is not massive. However, the movement experienced a peak when on June 16, 2014. At that time the right moment for them to make substantial resistance. The rejection action organised by mothers when the first stone will be placed symbolically by the Semen Indonesia Company [9]. According to one of their statements that the action takes place in an uproar. Which then leads to physical violence committed by the data safety. Many women are thrown into the undergrowth, causing bruising part of their body, and some even fainted. But the incident later did not dampen the efforts of their struggle. At the time it was then they decided to set up "Struggling Tent" [10].

Efforts to fight they do not just stop at the tent struggle. There are many ways to through legal action or resistance symbolically addressed to the state. They repeatedly attended the trial held in the Administrative Court and the Administrative Court Semarang-Surabaya from Rembang; engage in dialogue with the governor [11] and even with the President; take action to denounce the witness UGM academicians who plays as an expert witness in the trial of disputes between peasants twilight with Semen Indonesia Company [12]; set up a struggling tent in front of the president's palace; do a long march of hundreds of kilometers of Pati Semarang; conducting cultural rituals; and even the actions taken by the mothers Kendeng is when nine of the members stocks their feet with cement when in Jakarta.On the other hand, it is very interesting that the various mobility actions by the women in Rembang are doing the 
funding independently. Which means any activity that demands action women have to travel far to finance them independently. But until now still get a stigma if their movement was funded the effort by certain parties. And even among some of the actions for which they did get stigmatization of communism, same with communist stigmatization as a propaganda tool of the new order they were assigned to the public that during the Suharto regime to the rejection of the model of development policies related to the agrarian sector.However, many developing discourses to question the position of men in the resistance. Many people who make criticisms that as if women were sacrificed. Ms. Asha, as one informant, stating that the insurgency led by the mothers is one of the strategies of resistance. They learned from previous resistance effort led by men has always led to the forcible dissolution action and led to acts of violence committed by security forces against the peasants. Then it would be easy to form a public opinion so as to give effect to the community to have the action of solidarity with Rembang women though sometimes merely through social media [13].

\subsection{Implication of Ecofeminism on Rembang Movement}

Ecofeminism is part of the third wave feminists who try to explain the relationship of nature and especially women who became the focal point is the destruction of nature which is of direct relevance to the oppression of women. According to Vandana Shiva, Indian Ecofeminist, Third World development experienced childbirth myths are increasingly putting its citizens on the unfair conditions. Development practised Western countries always use psychological violence, economic, and physical [14]. According to Shiva, humans are the cause of the destruction of earth quality[14]. Human judged too selfish, regardless of the result of the earth. The environmental damage caused by mental and anthropocentric reasoning that is not friendly to nature.

Ecofeminism in Khalid's view is actually the point of view to analyse the environmental problem by using a knife feminist analysis [14]. Feminism clearly and in assessing the root of the problem, the impact, in particular on the specific vulnerable groups include women, and what underlies this movement to hold a large and widespread.Researcher tracking and comparing the women leadership in the social movement. In the research of Sarkar the women movement in India against the landlord of paddy field focusing on relations about labour and landlord [15]. Women in Rembang concern about environmental conservation. Rumini, one of our informant told about their worries if the cement factory was built in their land. Rumini worried about their environment will change and became destruct after the factory establish [16]. Horkheimer said the natural instinct of a human is about to self-preservation their nature and homeland [17].

In the implication of ecofeminism approach, the researcher takes some data and analogy from the informant to look up how the context of the motherland in their mind became the inspiration of this movement. Women in Rembang made a campaign in the public sphere (social media) about ideas relations of the motherland, nature, and her movement.The move becomes easy to remember by the public because the public's understanding also intensified that women have a natural bond that is so strong with the earth. The women's Rembang believes that their presence on earth to care for nature. Besides the problems that often arise at the beginning of their struggle there, is feeling tired. In reality, the woman always becomes dominated side by the capitalist. In this context, women in Rembang got warmed up because of government policy and Semen Indonesia factory that took off their land. The women in Rembang, together with their family and their children used to live and work in the agriculture sector, but it was changed to the industry sector. In fact, industry destroyed life and around 
their environment. In the theory aspect, the state will give the legality of domination practice towards women. State as a manifestation of high capitalist imprison woman rights that want to survive their nature. Foucault with his theory said that this is a new version of a total state institution to marginal women [18]. According to the theory of nature, the woman is soft, mercy, and comfort. A woman cannot work harder, irrational thinker, and cannot survive in a bad situation. But, in this case of Rembang's woman will break up the nurture theory. This discourse will examine with critical thinking theory, Beauvoir explains how the woman is implicated as "the other or second sex" for man needs. The woman can serve herself become "self (servant)" for their master (state) as the only domination to woman's body[19].

The natural environment that destroyed as Consequence Mountain Kendeng's exploitation sure can make the woman against that activity. The woman became angry because their nature that destroyed certain has power for mobilising the other women for doing their resistance to Cement Factory. They were fighting out for the rights and their nature that took by Semen Indonesia factory who cannot give the responsibility towards nature. It is kind of woman's leadership that become part of the woman's existence from their nature. The woman can take the movement for defending their nature. They can strike for their rights that discriminated by capitalist and state. The women are stronger than the man because they are a leader for their self and their family.In the view of Lestariningsih and Wariyantun, Rembang's movements, with women as the leader of the resistance, fully back up by the support of religious leaders in Rembang and surrounding areas. Islamic Preacher and National Figure like Ahmad MustofaBisri (Gus Mus) declared why resistance of Rembang's Women became important [2]. He asks to consider the environmental impact of mining activities, not only in Rembang but also in National level [2].

\subsection{Next Step Forward: Women Leadership as Trigger of Movement}

The women that live at around Kendeng's mountain used to interact with nature. They do their activity for cooking, washing, and the household job always together with nature. Semen Indonesia factory does not think the large impact from the exploitation. The women who live with nature need to release their rights. The women want to show their existence with made the movement, challenge the state and the power of capitalist for life survival. The resistance did with many aspects and methods, like protest movement until law path. But state and capitalist always break up the women spirit. The long state wants to force the women's body against their self and their nature. The elite is examining women's powerlessness to fight injustice. The frontal movement not only became the job of man but also women can against suppression towards their body.Those movements will be able they do because of the elite and the capitalist that manifested as Semen Indonesia factory disturbed their nature. Nature will be said as the pregnant woman. They will give their everyday life for serving and protect nature where the place they live. They are loyal to entrust soul and life for protecting the nature from irresponsibility side. This is one of the movements from Rembang's woman in Kendeng for surviving nature as a part woman's life. No one can be predicted until when the women in Rembang still struggling. But, the movement still is alive for nature life and the struggling of their lives. 


\section{Acknowledgements}

Susilo would like to express their gratitude to Airlangga University, especially to Dr.RahmaSugihartati and Dr.Diah Ariani Arimbi. Kodir would like to express their gratitude to The State University of Malang.

\section{References}

[1] D. Candraningrum, "Politik Rahim Perempuan Kendeng Menolak Tambang Semen," 2014 .

[2] D. Lestariningsih and D. Wariyatun, “"nDuweni Ibu Pertiwi” (Kepping the Motherland): Women's agency to resist cement plants in Tegaldowo and Tibrangan Villages, Rembang Asian," J. Women's Stud., vol. 21, no. 2, pp. 166-179, 2015.

[3] K. Klenke, Women and leadership: A contextual perspective. New York: Springer Publishing Company, 2004.

[4] Ihsanudin, "Petani Kendeng Menang di MA Lawan PT Semen Indonesia," 2016. .

[5] D. E. Comstock, "A Method for Critical Research," in Knowledge and Values in Social and Educational Research, E. B. W. Feiberg, Ed. Philadelphia: Temple University Press, 1982, pp. 370-390.

[6] J. Miller and B. Glassner, "The 'Inside' and the 'Outside': Finding Realities," in Interview Qualitative Research: Theory, Method and Practice, D. Silverman, Ed. London: Sage, 2004, pp. 125-139.

[7] D. Susilo and A. Kodir, "Politik Tubuh Perempuan: Bumi, Kuasa, dan Perlawanan," J. Polit., vol. 1, no. 2, p. 320, 2016.

[8] P. Saukko, Doing research in cultural studies: An introduction to classical and new methodological approaches. Sage, 2003.

[9] Murtini, "No Title." .

[10] Garwani, "Personal interview." 2016.

[11] Rofiudin, "Penolak Pabrik Semen Temui Ganjar Pranowo." 2016.

[12] E. C. P, "Kecam Pernyataan Saksi Ahli, Ratusan Warga Rembang Demo UGM.” 2015.

[13] Asha, "Personal interview." 2016.

[14] K. Khalid, "Ekofeminis di Indonesia, Apakah Ada?" 2008.

[15] S. C. Sarkar, "The Role of women in Tebhaga movement in Jalpaiguri District and to preserve their identity African," J. Hist. Cult., vol. 6, no. 9, pp. 175-182, 2014.

[16] Rumini, "Personal interview." 2016.

[17] Sindhunata, Dilema Usaha Manusia Rasional. Jakarta: Gramedia, 1982.

[18] M. Dillon and A. Neal, 2015 Foucault on politics, security and war. Springer, 2015.

[19] S. de Beauvoir and K. Hutchings, Teori - Teori Kritis: Menantang Pandangan Utama Studi Politik Internasional. Yogyakarta: Pustaka Pelajar, 2013. 